\title{
THE CONCEPT OF HEDGING INSTRUMENT FORWARD IN ISLAMIC ECONOMIC PERSPECTIVE
}

\author{
Bambang Hidayat; Ayu Rahayu Nurhalizah; Andriani Samsuri; Eka Nurjannah \\ Universitas Islam Negeri Sunan Ampel Surabaya \\ e-mail: bambanghd0@gmail.com; ayurhayaunurhalizah6@gmail.com; \\ andriani@uinsby.ac.id; ekanurjannah2505@gmail.com
}

\begin{abstract}
This research aims at explaining more in-depth about Islamic hedging related to the problem of muwa'adah status in Islamic hedging. The use of muwa'adah as an Islamic hedging instrument which promises to carry out transactions in the future, actually still becomes a subject of debate since there are some different opinions about whether or not it is permissible to carry out the concept of muwa'adah in a transaction. This research is descriptive qualitative research and uses qualitative data analysis, by conducting a direct analysis of the hedging scheme through the process of data reduction, data display, and verification. The results of this study reveal that in sharia hedging, swap and forward contracts should not be used, because swaps and forwards contain elements of usury. While the option contract contains speculation (maysir). If the forbidden aspects (haram) in 'forward' and 'swap' instruments are analyzed, generating al-sarf al-ajil and maysir (khatär/speculation), then the alternatives are 1) forward agreement by way of a price-fixing agreement; 2) bay' al-iltizam; 3) bay' al- 'urbū; and 4) al-bay' bi al-shart.
\end{abstract}

Keywords: forward agreement; islamic hedging; muwäadah

\section{Introduction}

Sharia finance, which is increasingly advanced and growing very rapidly, is finally facing increasingly complex challenges. Islamic banking and financial institutions must be able to meet the needs of modern business by presenting innovative and more varied products and satisfying services. The forms of contracts in classical fiqh are no longer sufficient for this progress. Therefore, innovation and new creations are needed for the formation of contracts in classical fiqh to suit the needs and demands of today's society. In line with these developments, Islamic banks are required to always innovate so that the products offered can attract the interest of customers, as well as compete with conventional banks. Therefore, DSN-MUI always strives to present financing instruments that are following the needs of the times but still meet the rules of Islamic law. The ijtihad product of contemporary Muslim scholars is in the form of a hybrid contract concept or commonly referred to as multi-contract in Islamic finance financings such as ijärah muntahiyah bi al-tamlik, mushärakah mutanäqisah, Islamic hedging, debit transfer in banking, and others.

What is meant by hedging is one of the important risk management mechanisms. With this risk management, a company can avoid losses that may occur in the future. However, without good risk management, even if a company makes a profit, there will be potential losses due to foreign exchange risk or portfolio risk. This hedging mechanism can be used to protect 
institutions. ${ }^{1}$ This is important when there is a foreign exchange contract that involves transactions or trades between nations such as import payments and receipts of export goods.

Hedging as an effort to reduce financial risk is often used by companies that have relatively large transactions in foreign currencies. Where one of the reasons for choosing to hedge using a forward contract is the various flexibility possessed by a forward contract compared to other hedging techniques (forward contracts are more flexible because they are not standardized). So that the company can determine the value and maturity of the contract. However, this is also not a definite answer that by using a forward contract hedging a company can be free from the risk of losses that will arise in the future.

Allah revealed the teachings of Islam as a life guide that always accommodates the needs of mankind following the basic principles of business norms, namely the absence of speculation (gambling) which encourages unproductive business activities and usury transactions that result in economic exploitation by the owners of capital (riba nasi'ah) and jahiliyyah or those that do not grow the real sector through trade and exchange of similar goods that are usurious (riba $f a d l$ ). Based on this, the DSN-MUI has tried to issue a fatwa on sharia hedging or known as Islamic hedging. However, the fatwa has not fully provided a sufficient answer for the public. Because it is considered there are other considerations. As in the concept of forwarding contract hedging or muwäadah (mutual promise) itself, there are still many parties who think that muwa' 'adah is the same as a contract because it is mulzim, therefore the concept of muwa' ${ }^{-}$adah cannot be used as a sharia hedging instrument because it will cause doubts in the community. Because the concept cannot be used in sharf transactions because it contains elements of gharar and speculative elements.

From this description, concerns arise about the permissibility of entering into agreements and the obligation to fulfill promises to conduct transactions in the future at the exchange rate prevailing at the time the agreement was made, which is one of the hedging instruments. In hedging, an agreement is needed to protect the value against exchange rates that can change at any time. These changes can have a negative effect in the form of losses for a company. However, the agreement to conduct transactions in the future can also create uncertainty so that it can be considered as gharär. To provide this answer, DSN-MUI has tried to issue a fatwa on sharia hedging or known as Islamic hedging. However, the fatwa has not fully provided a sufficient answer for the public. Because it is considered that there are considerations that are considered contrary to the instructions or other arguments.

In terms of the obligation to keep promises, the scholars are divided into two opinions. First, the group of scholars stated that the obligation to fulfill the promise was only one of the parties who made the promise. This opinion was expressed by Yusuf al-Qardhawi who quoted Ibn Taymiyyah's opinion about tawarruq. Tawarruq as stated by Ibn Abbas in Majma' Fatawa Ibn Taimiyyah, as quoted by al-Sya'rawi, namely if someone buys an item in cash then that person sells it back to someone else with tough. ${ }^{2}$ The second opinion is the opinion of the ulama which states that the promise must be fulfilled by both parties who agree. Among the scholars

\footnotetext{
${ }^{1}$ Azlin Alisa and Ahmad Mustafa Afifi Ab. Halim, "The Concept of Hedging in Islamic Financial Transactions", Asian Social Science, Volume 10, Number 8 (2014), 42-49.

${ }^{2}$ Ayd Fadl Al-Sya'rawi, al-Masharif al-Islamiyyah Dirasah Amaliyyah Fiqhiyyah li al-Mumarasah al-Amaliyyah (Beirut: Dar al-Jami'ah li al-Thaba'ah wa al-Nasyr, 2007), 204.
} 
who expressed this opinion, namely Muhammad Abd. Halim. This opinion is based on several things including, the fulfillment of promises made by the parties not contrary to the Sharia, the necessity of keeping promises, the willingness of both parties to carry out the promises, promises are not the same as buying and selling. ${ }^{3}$

Besides that, there is an opinion that states otherwise, according to the ijtima ${ }^{-}$, carried out by the OIC Number 65 concerning the capital market, as quoted by Erwandi Tarmizi, states that it is not allowed to make promises in terms of currency exchange, this is because the Sharia does not allow buying and selling of currencies that are not carried out in cash. Likewise, the SOP for world Islamic financial institutions issued by the AAOIFI (Accounting and Auditing Organization for Islamic Financial Institutes) in Bahrain states that the promise to exchange foreign currency that is binding is haram even though it aims to hedge, this is because binding promises are equated by contract. Besides that, the handover of foreign currency is not carried out directly after the promise is made. ${ }^{4}$ A similar opinion was also expressed by Veithzal Rivai that muwa'adah or mu'ahadah (bilateral agreements) are not permitted in situations where 'aqd is not permitted such as currency forward contracts. ${ }^{5}$

From some of the explanations above, hedging according to the author can be interpreted as a way to protect the value from fluctuations in the exchange rate, which can be done by promising each other to carry out a transaction in the future by determining the exchange rate as applicable when the agreement was made. Regarding the promise to carry out transactions in the future, there are still differences of opinion about whether or not it is permissible to carry out the concept of muwa adah in a transaction.

\section{Research Methods}

This research is a qualitative descriptive study. Qualitative descriptive research is research that describes or describes the object of research based on the facts that appear or as they are. The data used in this study is secondary data obtained from various reference sources, both articles in journals, books, and other documents relevant to the research. The data collection technique that the author uses is library research. As the main instrument is the researcher himself, in this case, the researcher will read, observe, and record things related to the research objectives.

In this study, the author uses qualitative data analysis, namely by conducting a direct analysis of the hedging scheme through the process of (1) data reduction, namely the author selects and sorts out the data to be analyzed in the form of words, sentences, or expressions according to the method direct and indirect methods; (2) data display, namely the author displays the data that has been selected and sorted and analyzes the type of method; (3) verification, namely the author concludes the results of the analysis on the use of the method used.

\section{Islamic Hedging}

\footnotetext{
${ }^{3}$ Ibid.

${ }^{4}$ Erwandi Tarmizi, Harta Haram Muamalat Kontemporer (Bogor: Berkat Mulia Insani, 2012), 88.

${ }^{5}$ Veithzal Rivai, Islamic Banking and Finance: dari Teori ke Praktik Bank dan Keuangan Syari'ah Sebagai Solusi dan Bukan Alternatif (Yogyakarta: UII Press, 2012), 74.
} 
Hedging is known in Arabic terms as al-tahawwut al-islami. DSN MUI Fatwa Number 96 of 2015 explains that the purpose of al-tahawwut al-islami/Islamic hedging on exchange rates is a method or technique to reduce risks that arise or are expected to arise due to exchange rate fluctuations. The development of financial institutions, especially banking, will be followed by the complexity of the risks involved in the business activities themselves, thus requiring good corporate governance practices and the application of risk management. The application of risk management will provide benefits, namely providing an overview to the manager regarding the possibility of losses to the institution/bank in the future. Islamic hedging is part of minimizing the risk to finance in Islamic banks. ${ }^{6}$

In Indonesia, the application of hedging carried out by companies that carry out business according to Sharia principles must comply with the fatwa of DSN MUI Number 96/DSNMUI/IV/2015 concerning sharia hedging transactions on exchange rates. All Islamic financial institutions wishing to hedge must comply with the fatwa. It is explained there that Sharia hedging transactions on exchange rates can use one of the following contracts: ${ }^{7}$

1. 'Aqd al-tahawwut al-basit, namely hedging transactions with a forward agreement scheme followed by spot transactions at maturity and settlement in the form of currency handovers. The mechanism of Islamic hedging transactions on exchange rates with 'aqd al-tahawwut al-basit is that the parties promise each other (muwäadah), either in writing or unwritten, to carry out one or more spot transactions in the future which includes agreement on the currency being traded, nominal amount, exchange rate or exchange rate calculation, and execution time. At the time of execution, the parties carry out spot transactions (ijjab qabul) at an agreed price followed by the handover of the currency exchanged.

2. 'Aqd al-tahawwut al-murakkab, namely hedging transactions with a scheme in the form of a series of spot transactions and forward agreements followed by spot transactions at maturity and settlement in the form of currency handovers. The mechanism of this contract is that the parties carry out spot transactions and promise each other (muwa $a$ adah) to carry out one or more spot transactions in the future which includes an agreement on the currency being traded, nominal amount, exchange rate, or exchange rate calculation, and time. implementation. At the time of execution, the parties carry out spot transactions ( $\overline{i j} a b$ qabuil) at an agreed price followed by the handover of the currency exchanged.

3. 'Aqd al-tahawwut fi süq al-sil'ah, namely hedging transactions with a scheme in the form of a series of commodity buying and selling transactions (sil'ah) in rupiah currency followed by commodity trading (sil'ah) in foreign currency and the settlement is in the form of currency handover at maturity. The mechanism of the contract is different from the mechanism of the two contracts above, where there are two transactions carried out in this 'aqd al-tahawwut fi süq al-sil'ah contract.

In some of these transactions that allow banks to use there are two contracts, namely 'aqd al-tahawwut al-basit and 'aqd al-tahawwut al-murakkab, because the contract uses the same mechanism of spot and forward agreement. However, for 'aqd al-tahawwut fi süq al-sil'ah,

\footnotetext{
${ }^{6}$ Dede Abdurahman, “Analisis Transaksi Lindung Nilai Syariah (al-Tahawwut al-Islami/Islamic Hedging) atas Nilai Tukar,” Jurnal Ecopreneur: Jurnal Ekonomi dan Bisnis Islam, Volume 4, Number 1 (2020), 55-72.

${ }^{7}$ Muhammad Anwar Fathoni and Suryani, "Lindung Nilai (Hedging) Perspektif Islam: Komparasi Indonesia dan Malaysia,” INFERENSI Jurnal Penelitian Sosial Keagamaan. Volume 11, Number 2 (2017), 47-59.
} 
Islamic banks cannot use it because the transaction requires commodities, so it is more appropriate to use it on the commodity exchange. Therefore, many entrepreneurs transact using a sharia-compliant foreign exchange that is free from speculation. In this case, the author takes the theme of forwarding exchange contracts, or can be called Islamic foreign exchange forwards published by IIFM as a source of fatwas for international Islamic countries.

A forward exchange contract (FEC) is a business agreement whereby an agreement to buy a certain amount of foreign currency at a certain date in the future. Purchases are made at a predetermined exchange rate. By entering into this contract, the buyer can protect himself from subsequent fluctuations in foreign exchange rates. The purpose of these contracts is to hedge foreign exchange positions to avoid losses or to speculate on future changes in exchange rates to generate profits.

By signing a forward contract, the company can ensure that certain future obligations can be settled at a certain exchange rate. Forward contracts are usually adjusted, and arranged between the company and the bank. The bank will require partial payment to enter into the forward contract, as well as the final payment before the settlement date. The FEC rate is worse than the spot rate prevailing on the value date. FEC is out of money and the number of contracts is more than required. It requires buying or selling an excess amount of foreign exchange but the prevailing spot rate is worse than the FEC benchmark (FEC rate). FEC is in the money and fewer contracts are required. This entails buying or selling an additional amount of currency at the prevailing spot rate but a rate worse than the FEC benchmark. ${ }^{8}$

Islamic forward exchange is a wa'ad or promise-based contract designed as a hedging mechanism to minimize the exports of market participants with exchange rates that continue to move and fluctuate. The definition of wa'ad in Islamic civil law is a promise, namely ikhbara insya al-mukhbir ma'rúfan li al-mustaqabal, a statement intended by the giver of the statement to do good deeds in the future. Another meaning is the desire expressed by someone to do something, both deed, and speech, to provide benefits to the other party. ${ }^{9}$

In some cases, existing Islamic banks are still experiencing difficulties. This happens because there are several Islamic commercial banks that have not been involved in the foreign exchange industry. In addition, the existence of provisions means that there are only a few banks that are capable of conducting foreign exchange transactions. Concerning clarifying the comparison between contracts issued by the DSN-MUI fatwa with Islamic foreign exchange forwards or forward exchange contracts that have been recognized by international legal entities so that they can be implemented in Indonesia and can also increase the performance power of Islamic banks in engaging in the foreign exchange industry so that they can be avoided. from the risk of foreign exchange transactions.

\section{Analysis of Islamic Hedging Forward Instruments (Muwäadah)}

Hedging (al-tahawwut) to reduce risks that arise or are expected to arise due to price fluctuations in financial markets. That is, managing the exchange rate risk on the exposure faced

\footnotetext{
${ }^{8}$ Amin Fauzi and Rachmat Adji Fahreza, "Implementasi Fatwa DSN-MUI No. 96/Iv/2015 Tentang Transaksi Lindung Nilai pada Transaksi Forward Exchange Contract," Jurnal Ekonomi Islam, Volume 9, Number 1 (2018), 27-45.

${ }^{9}$ Ibid.
} 
by Islamic financial institutions as a result of the mismatch of the exchange rate between the local currency (domestic currency) and the volatility of foreign currency exchange rates (foreign currency) in meeting bank obligations in the future (future) exposure (al-hajah almustaqbaliyah). ${ }^{10}$

Hedging is done by fixing the exchange price at a certain exchange rate to anticipate losses due to the increase or decrease in the value of foreign exchange utilizing forwards or swaps or options. The business can make big profits, but it can be a loss because the exchange rate is low. In banking, foreign exchange hedging, among others, is for 1) maintain the foreign exchange value of all third-party funds (current accounts, savings, time deposits, interbank and foreign loans). This safeguard is carried out so that the value of foreign exchange remains at its nominal value when needed. This is done by making sales contracts today (spot) and repurchasing from other parties for future delivery (forward), or vice versa, buying today and selling to other parties for a certain period. In Islamic banking, this is also implemented because on the side of raising funds, Islamic banks also open checking accounts (wadi' $a h$ ), savings accounts (mudârabah), and deposits (mudärabah) in foreign currencies. Likewise, interbank placements and foreign loans. Such as current accounts, savings, time deposits, PKLN, and I/B. For example, demand deposits in the DSN fatwa are qard (loans), then the bank as the debtor has an interest in hedging demand deposits so that when they are returned, the price of foreign exchange does not increase. For example, in foreign exchange (dollar) demand deposits, when a customer places a deposit with a bank, the price is in dollars 14,000 , but this price has the potential to rise to 14,500. Then the bank hedged the demand deposit at the exchange rate of $14,000 ; 2)$. maintain the value of foreign currency for financing assets. Funding provided in foreign currencies is generally hedged to keep it at the expected nominal, both in total and in installment payments, such as murabahah, mudärabah, and ijarah transactions using dollars. For example, Bank A provides murabahah financing to customers in the form of tractor purchases. Then bank A buys a tractor from a dealer. Usually, tractors are sold in dollars. If the bank is concerned that the dollar exchange rate will rise, the bank will conduct hedging transactions with Bank B with the LC as the underlying asset and the customer paying the premium. In these two transactions, the swaps made can be expanded by adding options, namely variations in terms of purchase/sale transactions. For example, a bank will buy back the foreign currency that it sells at an agreed price if the market price is higher. ${ }^{11}$

Referring to the difference between conventional hedging and sharia hedging, it is contained in the contract/contract instrument used. In conventional hedging, you can use forwards, options, or swaps. Meanwhile, in sharia hedging, it is only allowed to use a forward agreement/muwäadah. Sharia hedging may not use swap and forward contracts, because swaps and forwards contain elements of usury. While the option contract contains speculation (maysir). ${ }^{12}$

The basics used as arguments for the permissibility of hedging transactions are:

\footnotetext{
${ }^{10}$ Setiawan Budi Utomo, Analisis Kesesuaian Instrument Hedge Konvensional Terhadap Prinsip Syariah, n.d.

${ }^{11}$ Ibid.

${ }^{12}$ Lina Ade Chusmita dan Sahlan Hasbi, “Analisis Penerapan Hedging di Perbankan Syariah Indonesia," Jurnal Nisbah, Volume 2, Number 2 (2016), 295.
} 


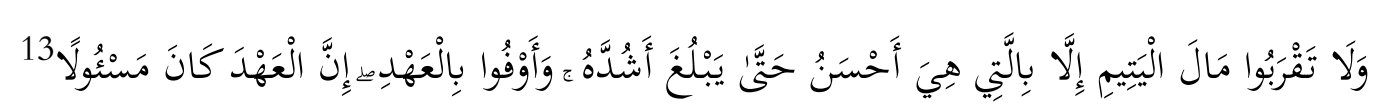

"And do not approach the property of an orphan, except in a better way (beneficial) until he grows up and fulfills his promise; In fact, the promise must be held accountable"14

Hadith of the Prophet narrated by Ibn Majah from 'Ubadah ibn Shamit, the history of Ahmad from Ibn 'Abbas, and the history of Imam Malik from Yahya:

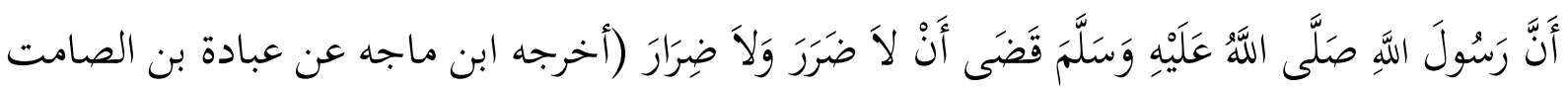

$$
\begin{aligned}
& \text { في سننه, الكتاب: الأحكام، الباب : من بنى في حقه مايضر بجاره، رقم الحديث : اسبسب، ورواه } \\
& \text { أحمد عن ابن عباس، ومالك عن يجي) }
\end{aligned}
$$

"Rasulullah S.A.W. stipulates: it is not permissible to harm/harm others and (also) to repay the harm (loss inflicted by others) with danger (an action that harms him)." (Narrated by Ibn Majah from Ubadah bin Shamit in his Sunan, book: Ahkam, chapter: man bana bi haqqihi ma yadhurru bijarihi, No: 2331; HR Ahmad from Ibn Abbas, and HR Malik from Yahya)

The origin of an economic transaction, including in this case a hedging transaction, is permissible based on the rule of law. The origin of the transaction is permissible until there is an argument that prohibits the activity. As explained by Sami al-Suailem above that hedging can not only minimize the risk of foreign exchange fluctuations but in its implementation sometimes there is also an element of gambling or speculation. One of the prohibitions when conducting hedging transactions is to speculate or chance. The most widely used hedging instrument in the Islamic finance industry is the forward plus swap instrument. While pure forward instruments without swaps are still rarely used.

\section{Conclusion}

In Indonesia, the application of hedging carried out by companies that carry out business according to Sharia principles must comply with the fatwa of DSN MUI Number 96/DSNMUI/IV/2015 concerning sharia hedging transactions on exchange rates. All Islamic financial institutions wishing to hedge must comply with the fatwa. It is explained there that Sharia hedging transactions on exchange rates can use one of the 'aqd al-tahawwut al-basit, 'aqd altahawwut al-murakkab, and 'aqd al-tahawwut fi súq al-sil'ah. In sharia hedging, it is only allowed to use a forward agreement/muwa' adah. Sharia hedging may not use swap and forward contracts, because swaps and forwards contain elements of usury. While the option contract contains speculation (maysirir).

If the forbidden aspects (haram) in the forward and swap instruments are analyzed, namely al-șarf al-ajil and maysïr (khatär/speculation), then the alternatives are 1) forward agreement by way of a price-fixing agreement, not a contract but only an agreement (promise); 2) bay' al-iltizam using reinterpretation that the object of the contract is not money but rights. According to Nazih Hammad, rights are valuable and can be traded; 3) bay' al- 'urbün, the

\footnotetext{
13 al-Quran, 17: 34

${ }^{14}$ Kementerian Agama Republik Indonesia, Al-Quran dan Terjemahnya (Jakarta: Kemenag Press, 1995$), 739$.
} 
premium which is usually paid as interest for hedging services is replaced with a down payment under the 'urbun scheme; 4) al-bay' bi al-shart, the contract is with the condition that the price is normal, if not, then it is not a transaction.

\section{Bibliography}

Alisa, Azlin and Ahmad Mustafa Afifi Ab. Halim. "The Concept of Hedging in Islamic Financial Transactions", Asian Social Science, Volume 10, Number 8 (2014).

al-Sya'rawi, Ayd Fadl. al-Masharif al-Islamiyyah Dirasah Amaliyyah Fiqhiyyah li alMumarasah al-Amaliyyah. Beirut: Dar al-Jami'ah li al-Thaba'ah wa al-Nasyr, 2007.

Tarmizi, Erwandi. Harta Haram Muamalat Kontemporer. Bogor: Berkat Mulia Insani, 2012.

Rivai, Veithzal. Islamic Banking and Finance: dari Teori ke Praktik Bank dan Keuangan Syari'ah Sebagai Solusi dan Bukan Alternatif. Yogyakarta: UII Press, 2012.

Abdurahman, Dede. "Analisis Transaksi Lindung Nilai Syariah (al-Tahawwut alIslami/Islamic Hedging) atas Nilai Tukar," Jurnal Ecopreneur: Jurnal Ekonomi dan Bisnis Islam, Volume 4, Number 1 (2020).

Fathoni, Muhammad Anwar and Suryani. "Lindung Nilai (Hedging) Perspektif Islam: Komparasi Indonesia dan Malaysia," INFERENSI Jurnal Penelitian Sosial Keagamaan. Volume 11, Number 2 (2017).

Fauzi, Amin and Rachmat Adji Fahreza. "Implementasi Fatwa DSN-MUI No. 96/Iv/2015 Tentang Transaksi Lindung Nilai pada Transaksi Forward Exchange Contract," Jurnal Ekonomi Islam, Volume 9, Number 1 (2018).

Utomo, Setiawan Budi. Analisis Kesesuaian Instrument Hedge Konvensional Terhadap Prinsip Syariah, n.d.

Chusmita, Lina Ade dan Sahlan Hasbi. "Analisis Penerapan Hedging di Perbankan Syariah Indonesia," Jurnal Nisbah, Volume 2, Number 2 (2016).

Kementerian Agama Republik Indonesia. Al-Quran dan Terjemahnya. Jakarta: Kemenag Press, 1995. 